THE EFFECT OF CORPORATE SOCIAL RESPONSIBILITY, INSTITUTIONAL OWNERSHIP AND ASYMMETRY INFORMATION ON COST OF EQUITY CAPITAL WITH EQUITY BOOK VALUE AS MODERATED VARIABLE (STUDY ON NON-FINANCIAL INSTITUTION COMPANIES IN LQ-45 INDEX IN 2015 - 2018)

\title{
PENGARUH CORPORATE SOCIAL RESPONSIBILITY, KEPEMILIKAN INSTITUSIONAL DAN ASIMETRI INFORMASI TERHADAP COST OF EQUITY CAPITAL DENGAN NILAI BUKU EKUITAS SEBAGAI VARIABEL MODERASI (STUDI PADA PERUSAHAAN NON LEMBAGA
} KEUANGAN DALAM INDEKS LQ-45 TAHUN 2015 - 2018)

\author{
Oleh: \\ Edison Vain $\mathbf{S}^{1)}$, Afrizal' ${ }^{2}$, Yudi ${ }^{3)}$ \\ 1)Alumni Magister Ilmu Akuntansi Pascasarjana Universitas Jambi Tahun 2020 \\ ${ }^{2 \& 3)}$ Dosen Fakultas Ekonomi dan Bisnis Universitas Jambi \\ Email: florensicje@gmail.com ${ }^{1)}$ afrizaldoktor@unja.ac.id ${ }^{2)}$ yudi_fe@unja.ac.id ${ }^{3)}$
}

\begin{abstract}
This research examines the Effect of Corporate Social Responsibility, Institutional Ownership and Information Asymmetry on Cost of Equity Capital with Book Value of Equity as a Moderation Variable (Study on Non-Financial Institution Companies in LQ-45 Index 2015 - 2018). This study aims to determine the pattern of causal relationships between the independent and dependent variables in 26 non-financial institution companies incorporated in LQ-45 from 2015 - 2018, using secondary data, quantitative approaches and analysis using panel data regression.

Disclosure of Corporate Social Responsibility does not affect the Cost of Equity Capital. Institutional ownership does not affect the cost of equity capital. Information asymmetry has a positive and significant effect on the cost of equity capital. The interaction between the book value of equity with corporate social responsibility does not affect the cost of equity capital. The interaction between the book value of equity and institutional ownership has a positive and significant effect on the cost of equity capital. The interaction between the book value of equity with information asymmetry has a significant negative effect on the cost of equity capital.
\end{abstract}

Keyword: Cost of Equity Capital, Corporate Social Responsibility, Institutional Ownership, Information Asymmetry, and Equity Book Value.

\section{ABSTRAK}

Penelitian ini bertujuan untuk mengetahui bagaimana pengaruh corporate social responsibility, kepemilikan institusional dan asimetri informasi terhadap cost of equity capital dengan nilai buku ekuitas sebagai variabel moderasi pada perusahaan non lembaga keuangan dalam indeks LQ-45 tahun 2015 - 2018. Penelitian ini bertujuan mengetahui pola hubungan kausal antara variabel independen dan variabel dependen pada 26 perusahaan non lembaga keuangan yang tergabung dalam LQ-45 dari tahun 2015 - 2018, dengan menggunakan data sekunder, pendekatan kuantitatif dan analisis menggunakan regresi data panel.

Pengungkapan Corporate Social Responsibility tidak berpengaruh terhadap Cost of Equity Capital. Kepemilikan institusional tidak berpengaruh terhadap cost of equity capital. Asimetri informasi berpengaruh positif dan signifikan terhadap cost of equity capital. Interaksi antara nilai buku ekuitas dengan corporate social responsibility tidak berpengaruh terhadap cost of equity capital. Interaksi antara nilai buku ekuitas dengan kepemilikan institusional berpengaruh positif dan signifikan terhadap cost of equity capital. Interaksi antara nilai buku ekuitas dengan asimetri informasi berpengaruh negatif dan signifikan terhadap cost of equity capital.

Kata Kunci: Cost of Equity Capital, Corporate Social Responbility, Kepemilikan Institusional, Asimetri Informasi, Nilai Buku Ekuitas. 


\section{PENDAHULUAN}

\subsection{Latar Belakang}

Tandelilin (2001) menjelaskan bahwa investor lebih menyukai perusahaan yang mengungkapkan lebih banyak informasi tentang perusahaannya, dengan demikian mereka menganggap risiko perusahaan tersebut rendah. Apabila risiko perusahaan dianggap rendah oleh investor maka tingkat return yang diminta juga rendah. Dengan demikian tingkat biaya modal (cost of equity capital) yang dikeluarkan perusahaan juga rendah. Made (2015) mendefiniskan biaya modal sebagai tingkat pendapatan minimum yang disyaratkan pemilik modal. Dari sudut pandang perusahaan yang memperoleh dana, tingkat pendapatan yang disyaratkan tersebut merupakan biaya atas dana yang diperoleh perusahaan. Besar kecilnya biaya modal suatu perusahaan tergantung pada sumber dana yang digunakan perusahaan untuk membiayai investasi, khususnya sumber dana yang bersifat jangka panjang.

Halim (2012) menngungkapkan bahwa biaya modal merupakan konsep penting dalam analisis investasi karena dapat menunjukan tingkat minimum laba investasi yang harus diperoleh dari investasi tersebut. Jika investasi itu tidak dapat menghasilkan laba investasi sekurangkurangnya sebesar biaya yang ditanggung maka investasi itu tidak perlu dilaksanakan. Konsep biaya modal dimaksudkan untuk menghitung besarnya biaya yang nyata-nyata ditanggung oleh perusahaan sehubungan dengan penggunaan dana dari suatu sumber. Hasil perhitungan tersebut antara lain akan digunakan sebagai dasar untuk pengambilan keputusan menerima atau menolak suatu usulan investasi.

Penelitian mengenai cost of equity capital dalam penelitian ini dilakukan pada perusahaan yang terdaftar dalam indek LQ-45. Perkembangan rata-rata biaya modal ekuitas (cost of squity capital) pada perusahaan yang terdaftar dalam indeks LQ-45 dalam periode tahun 2015 - 2018 dapat dilihat pada grafik berikut ini:

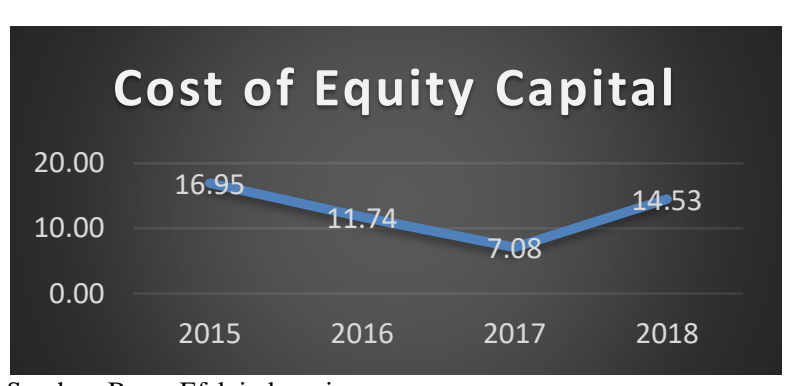

Sumber: Bursa Efek indonesia

\section{Gambar 1. Perkembangan Rata-rata Cost of Equity Capital pada Perusahaan yang Terdaftar dalam Indeks LQ-45 Tahun 2015 - 2018}

Gambar 1 menunjukkan adanya penurunan yang cukup signifikan nilai cost of equity capital pada perusahaan yang terdaftar dalam indeks LQ-45 dari tahun 2015 - 2017 dari 16,95 menjadi 7,08. Pada tahun 2018 , nilai cost of equity capital kembali mengalami peningkatan yang sangat besar dari 7,08 menjadi 14,53. Fluktuasi rata-rata cost of equity capital yang terjadi selama periode tahun 2015 - 2018 tersebut tentunya dipengaruhi banyak faktor baik faktor dari internal perusahaan maupun eksternal perusahaan. Keown, et.al (2000) mengungkapkan bahwa perkembangan cost of equity capital dipengaruhi oleh kondisi perekonomian secara umum yang digambarkan dalam tingkat pengembalian bebas resiko, resiko pasar yang ditunjukkan oleh nilai return pasar, keputusan operasi dan keuangan perusahaan dan struktur modal perusahaan.

Pengukuran biaya modal (cost of equity capital) dilakukan menggunakan metode Capital Asset Pricing Model (CAPM) merupakan tingkat return yang diharapkan oleh investor sebagai kompensasi atas risiko yang tidak dapat dideversifikasi Oleh karena itu, besarnya nilai cost of equity capital sangat berhubungan dengan besaran return saham yang diharapkan yang biasanya diukur menggunakan return pasar pada indeks harga saham gabungan (IHSG). Perkembangan return saham gabungan sangat mempengaruhi besarnya tingkat return yang diharapkan oleh investor pada saat melakukan investasi pada perusahaan-perusahaan yang terdaftar di bursa saham (Purwanto, 2014).

Karakteristik saham LQ45 ini dapat mewakili kinerja portofolio saham, dimana penilaian kinerja portofolio dilihat dari dua sisi yaitu imbal hasil dan risiko. Meskipun diisi oleh 45 saham perusahaanperusahaan yang memiliki banyak kelebihan jika dibandingkan dengan saham perusahaan-perusahaan lain, LQ45 juga tidak luput dari naik turunnya return. Sementara itu, nilai return saham perusahaan tidak terlepas dari perkembangan nilai return pasar dan return bebas resiko yang diukur dari nilai suku bunga. Perkembangan return pasar dan nilai suku bunga dapat dilihat pada tabel berikut ini.

Tabel 1. Return Pasar dan Return Bebas Resiko Tahun 2015 - 2018

\begin{tabular}{|c|c|c|c|c|}
\hline Indeks & 2015 & 2016 & 2017 & 2018 \\
\hline Return Pasar (\%) & -0.98 & 1,23 & 1,55 & $-0,17$ \\
\hline $\begin{array}{c}\text { Return Bebas } \\
\text { Resiko (\%) }\end{array}$ & 7,53 & 5,69 & 4,59 & 5,00 \\
\hline
\end{tabular}

Sumber: Statistik Pasar Modal, Otoritas Jasa Keuangan Tahun 2018

Tabel 1 menunjukkan bagaimana naik turunnya return pasar dan return bebas resiko yang diproksi menggunkan tingkat suku bunga Bank Indonesia. Nilai return pasar pada tahun 2015 - 2017 terlihat mengalami peningkatan dari $-0,98 \%$ menjadi $1,55 \%$, sedangkan pada tahun 2018 menurun menjadi $-0,17 \%$. Sementara itu, tingkat pengembalian bebas resiko menunjukkan kondisi sebaliknya dimana pada tahun 2015 - 2017 justru menurun dari 7,53 menjadi 4,59, dan sedikit mengalami peningkatan pada tahun 2018 menjadi $5,00 \%$. Kondisi ini menunjukkan bahwa cost of equity capital pada perusahaan cenderung mengalami perkembangan yang sama dengan tingkat pengembalian 
bebas resiko dan berbanding terbalik dengan return pasar.

Kecendrungan investor menyukai perusahaan yang lebih banyak informasi karena dianggap perusahaan tersebut memiliki resiko rendah, tentunya akan mempengaruhi tingkat pengungkapan yang dilakukan oleh perusahaan. Hughes et al (2006) menjelaskan bahwa pengungkapan informasi yang lebih luas oleh perusahaan akan dapat meningkatkan kesadaran investor atas keberadaan perusahaan dan memperbesar basis investor yang tentunya akan dapat mengurangi biaya modal (cost of equity capital). Selain itu, kualitas yang lebih tinggi atau lebih spesifik dari pengungkapan tersebut akan mengurangi kovarians dari arus kas sebuah perusahaan dengan arus kas dari perusahaan lain. Jenkins Committee dalam Suharsono dan Rahmasari (2013) menyatakan bahwa manfaat penting dari perluasan pengungkapan adalah semakin turunnya biaya modal (cost of equity capital).

Pengungkapan yang diharapkan oleh investor adalah tanggung jawab sosial dan lingkungan (corporate social responsibility), dimana pada dewasa ini perusahaan diharap oleh investor, pemerintah dan masyarakat tidak hanya berfokus pada pada shareholder saja namun juga stakeholder. Praktik tanggung jawab sosial dan lingkungan (corporate social responsibility) di Indonesia telah diatur dalam ketentuan perundang-undangan yaitu Undang Undang Nomor 40 tahun 2007 Tentang Perseroan Terbatas pada Bab IV Pasal 66 menjelaskan bahwa laporan keuangan tahunan perusahaan harus mencerminkan laporan kegiatan perseroan dan laporan pelaksanaan tanggung jawab sosial dan lingkungan (CSR) serta Undang Undang Nomor 25 tahun 2007 Tentang Penanam Modal pada Bab IX Pasal 15 yang menjelaskan bahwa setiap penanam modal wajib melaksanakan tanggung jawab sosial dan lingkungan (CSR). Laporan tahunan emiten sebagai sumber informasi penting bagi investor dalam keputusan investasinya juga telah memasukkan informasi tanggung jawab sosial dan lingkungan (CSR) sebagaimana hal ini diatur pada Keputusan Ketua Badan Pengawas Pasar Modal Dan Lembaga Keuangan Nomor : KEP-431/BL/2012.

Baker (2003) dalam Mardikanto (2018) mendefinisikan tanggung jawab sosial dan lingkungan (corporate social responsibility) adalah tentang bagaimana perusahaan mengelola proses bisnis untuk menghasilkan dampak positif secara keseluruhan pada masyarakat. Muljati (2011) dalam Mardikanto (2018) menjelaskan manfaat corporate social responsibility bagi perusahaan antara lain : meningkatkan citra perusahaan, memperkuat brand perusahaan, mengembangkan kerjasama dengan para pemangku kepentingan, membedakan perusahaan dengan pesaingnya, menghasilkan inovasi dan pembelajaran untuk meningkatkan pengaruh perusahaan, membuka akses untuk investasi dan pembiayaan bagi perusahaan, meningaktkan harga saham.
Sukarti dan Suwarti (2018) menjelaskan bahwa pengungkapan CSR melalui laporan keuangan dapat memberikan informasi lebih kepada investor. Sehingga tingkat pengungkapan CSR yang tinggi menciptakan kepercayaan investor terhadap perusahaan tersebut dan investor tertarik untuk menginvestasikan modalnya, sehingga dapat menurunkan cost of equity capital perusahaan. Murni (2004) dalam Rianingtyas dan Trisnawati (2017) menjelaskan bahwa semakin luas pengungkapan yang dilakukan oleh perusahaan yang diberikan kepada para investor atau pemegang saham akan menurunkan biaya transaksi dan risiko yang ditetapkan oleh investor tersebut yang pada akhirnya akan menurunkan biaya modal ekuitas.

Kepemilikan institusional merupakan persentase kepemilikan saham yang dimiliki oleh investor institusional seperti pemerintah, perusahaan investasi, bank, perusahaan asuransi maupun kepemilikan lembaga atau perusahaan lain. Sugiarto (2009) mendefinisikan struktur kepemilikan sebagai struktur kepemilikan saham yang dimiliki oleh orang dalam (insider) dengan jumlah saham yang dimiliki oleh investor atau dengan kata lain struktur kepemilikan saham adalah proporsi kepemilikan institusional dan kepemilikan managemen dalam kepemilikan saham perusahaan. Dalam menjalankan kegiatannya suatu perusahaan diwakili oleh direksi (agent) yang ditunjuk oleh pemegang saham (principals).

Cornett et al (2006) menjelaskan bahwa tindakan pengawasan perusahaan oleh kepemilikan institusional dapat mendorong manajer untuk lebih memfokuskan perhatiannya terhadap kinerja perusahaan sehingga akan mengurangi perilaku opportunistik atau mementingkan diri sendiri. Ashbaugh et al (2004) menjelaskan bahwa komposisi kepemilikan perusahaan bagi investor menunjukkan adanya jaminan atas investasi yang telah ditanamkannya, dimana dianggap dengan semakin besarnya institusi sebagai pemegang saham akan dapat mendorong pengawasan terhadap manajer dan kinerja perusahaan. Besarnya persentase kepemilikan institusional akan semakin meningkatkan transparansi manajemen dalam mengelola perusahaan. Tarjo (2010) mengungkapkan perusahaan yang memiliki kinerja yang baik tentunya akan direaksi oleh pasar dalam bentuk meningkatnya permintaan sekuritas perusahaan dan naiknya harga saham sehingga akan menurunkan cost of equity capital.

Faktor lain selain pengungkapan CSR dan kepemilikan institusional yang mempengaruhi cost of equity capital yaitu asimetri informasi. Hartono (2010) mendefinisikan asimetri informasi adalah kondisi yang menunjukan sebagian investor mempunyai informasi dan yang lainnya tidak memiliki.. Sugiarto (2009) menjelaskan bahwa asimetri informasi merupakan ketimpangan informasi antara manajer (agent) dengan investor atau pemegang saham (principal), dimana manajer dianggap lebih mengetahui lebih banyak informasi internal dan prospek perusahaan dimasa yang akan datang dibanding investor atau pemegang saham. 
Ketika timbul asimetri informasi, keputusan pengungkapan yang dibuat oleh manajer dapat mempengaruhi harga saham sebab asimetri informasi antara investor yang lebih terinformasi dan investor yang kurang terinformasi menimbulkan biaya transaksi dan mengurangi likuiditas yang diharapkan dalam pasar untuk saham perusahaan (Admadianto, 2017).

Penelitian ini menggunakan faktor nilai buku ekuitas sebagai variabel pemoderasi, dimana hal ini sesuai dengan penelitian sebelumnya bahwa nilai buku ekuitas sebagai variabel yang diproxikan dalam daya informasi akuntansi. Peneliti sebelumnya telah membuktikan adanya hubungan antara perubahan earnings dan book values serta kombinasi keduanya berpengaruh positif atau negatif pada cost of equity capital.

Yuniarta dan Agustini (2014) mengungkapkan bahwa nilai buku ekuitas terbukti mempengaruhi hubungan pengungkapan corporate social responsibility (CSR) dengan cost of equity capital (CEC) yakni memperlemah pengaruh positif CSR terhadap CEC. Semakin besar tingkat pengungkapan akuntansi yang dilakukan oleh perusahaan yang berupa pengungkapan CSR disertai dengan nilai buku ekuitas yang baik maka semakin rendah cost of equity capitalnya. Pengungkapan CSR dan nilai buku ekuitas yang baik merupakan keuntungan potensial dari pengungkapan. Keuntungan tersebut berupa meningkatnya jumlah investor, mengurangi estimasi risiko, dan mengurangi asimetri informasi yang masing-masing mengindikasikan pengurangan cost of equity capital perusahaan.

Hartono (2010) menjelaskan bahwa nilai buku ekuitas (book value equity) menunjukkan aktiva bersih (net asset) yang dimiliki oleh pemegang saham dengan memiliki satu lembar saham. Karena aktiva bersih adalah sama dengan total ekuitas pemegang saham, maka nilai buku per lembar saham adalah total ekuitas dibagi dengan jumlah saham yang beredar. Tandelilin (2001) menjelaskan bahwa hubungan antara harga pasar saham dan nilai buku per lembar saham bisa juga dipakai sebagai pendekatan alternatif untuk menentukan nilai suatu saham, karena secara teoritis, nilai pasar suatu saham haruslah mencerminkan nilai bukunya.

Nilai buku ekuitas berpengaruh positif terhadap harga saham dan bermanfaat dalam penilaian sekuritas. Peranan nilai buku tidak dapat diabaikan karena nilai buku juga merupakan informasi yang relevan dalam mempengaruhi keputusan ekonomi pemakai. Nilai buku merupakan ukuran neraca atau aktiva bersih yang menghasilkan laba. Nilai buku yang berasal dari neraca memberikan informasi tentang nilai bersih sumber daya perusahaan (Naimah dan Utama, 2006).

Penelitian mengenai pengaruh pengungkapan corporate social responbility terhadap biaya modal (cost of equity capital) masih menunjukkan hasil yang tidak konsisten. Penelitian-penelitian yang dilakukan Agustini (2011), Suharsono dan Rahmasari (2013), Xu,
Liu, dan Huang (2014), Jansen (2017), Rianingtyas dan Trisnawati (2017), Sukarti dan Suwarti (2018) mengungkapkan bahwa pengungkapan CSR terbukti berpengaruh terhadap cost of equity capital. Sementara itu dalam penelitian Sirait dan Siregar (2012), Razali, et.al (2017), menunjukkan hasil yang berbeda dimana dalam penelitian tersebut tidak ditemukan adanya hubungan positif antara pengungkapan corporate social responbility dengan cost of equity capital.

Sukarti dan Suwarti (2018) melakukan penelitian mengenai pengaruh kepemilikan institusional terhadap biaya modal (cost of equity capital). Hasil penelitiannya menunjukkan bahwa kepemilikan institusional mampu meningkatkan kinerja pasar saham dan menekan resiko jika investor membeli saham perusahaan, sehingga dengan turunnya resiko menyebabkan perusahaan memiliki kelonggaran untuk tidak harus mengungkapkan semua informasi mengenai kondisi perusahaan sehingga hal ini dapat menurunkan cost of equity capital. Hal ini sejalan dengan Amelia dan Yadnyana (2016) yang memiliki kesimpulan bahwa kepemilikan institusional memiliki pengaruh untuk menurunkan biaya ekuitas yang diterima oleh perusahaan. Penelitian lainnya Tarjo (2010) memberikan kesimpulan berbeda bahwa institusi sebagai pemegang saham institusional tidak mendapatkan reaksi positif pasar sekuritas dan harga saham sehingga tidak mampu mendorong perusahaan menciptakan cost of equity yang rendah.

Purwanto (2014) melakukan penelitian mengenai pengaruh asimetri informasi terhadap biaya modal (cost of equity capital), dimana penelitian tersebut menunjukkan bahwa asimetri informasi berpengaruh positif dan signifikan terhadap cost of equity capital sehingga dapat diartikan bahwa ketika timbul asimetri informasi maka keputusan pengungkapan yang dibuat manajemen dapat mempengaruhi harga saham. Pengaruh positif dan signifikan dari asimetri informasi terhadap cost of equity capital juga diungkapkan dalam penelitian yang dilakukan oleh Astutik, et.al (2018) dan Admadianto (2017) yang menyebutkan bahwa semakin kecil asimetri informasi dalam perusahaan maka cost of equity capital yang ditanggung oleh perusahaan akan semakin menurun, dengan kata lain terdapat hubungan positif antara asimetri informasi dengan cost of equity capital. Sementara itu dalam penelitian Rianingtyas dan Trisnawati (2017) menunjukkan hasil yang berbeda dimana asimetri informasi tidak berpengaruh cost of equity capital dan hal ini juga sejalan dengan Sukarti dan Suwarti (2018) yang menjelaskan bahwa setiap peningkatan asimetri informasi akan menurunkan cost of equity capital dan begitu sebaliknya.

Penelitian ini merupakan pengembangan dari penelitian yang dilakukan oleh Agustini (2011), untuk meneliti kembali hubungan corporate social responsibility dengan cost of equity capital yang dimoderasi oleh daya informasi akuntansi yang diproxikan dengan nilai buku ekuitas, namun pada penelitian ini menambahkan variabel kepemilikan institusional dan asimetri informasi ke dalam model 
penelitian serta langsung menggunakan nilai buku ekuitas sebagai variabel moderasi bukan lagi daya informasi akuntansi namun keduanya sama juga menggunakan nilai buku ekuitas sebagai variabelnya. Peneliti tertarik melakukan pengujian kembali hasil penelitian tersebut karena masih adanya inkonsistensi hasil pada penelitian-penelitian sebelumnya. Dalam hal ini peneliti menggunakan perusahaan yang terdaftar dalam indeks LQ-45 sebagai subjek penelitian. LQ 45 adalah indeks pasar saham di Bursa Efek Indonesia (BEI) yang terdiri dari 45 perusahaan dengan kapitalisasi tertinggi di pasar reguler dalam 12 bulan terakhir dan memiliki kondisi keuangan, prospek pertumbuhan dan nilai transaksi yang tinggi. Karakteristik tersebut membuat subjek yang diteliti memiliki karakteristik yang tidak berbeda jauh antara perusahaan satu dengan yang lain dilihat dari ukuran dan penggolongan jenis industrinya, sehingga peneliti tidak perlu melibatkan variabel kontrol ukuran perusahaan dan jenis industri seperti dalam penelitian sebelumnya.

Berdasarkan atas permasalahan di atas peneliti tertarik untuk melakukan penelitian dengan judul " Pengaruh Corporate Social Responsibility, Kepemilikan Institusional dan Asimetri Informasi terhadap Cost of Equity Capital dengan Nilai Buku Ekuitas sebagai Variabel Moderasi (Studi Pada Perusahaan Non Lembaga Keuangan Dalam Indeks LQ-45 Tahun 2015 - 2018)".

\subsection{Rumusan Masalah}

Berdasarkan latar belakang tersebut, maka rumusan masalah pada penelitian ini adalah sebagai berikut.

1. Apakah corporate social responsibility berpengaruh terhadap cost of equity capital ?

2. Apakah kepemilikan institusional berpengaruh terhadap cost of equity capital?

3. Apakah asimetri informasi berpengaruh terhadap cost of equity capital ?

4. Apakah nilai buku ekuitas memoderasi pengaruh corporate social responsibility terhadap cost of equity capital ?

5. Apakah nilai buku ekuitas memoderasi pengaruh kepemilikan institusional terhadap cost of equity capital?

6. Apakah nilai buku ekuitas memoderasi pengaruh asimetri informasi terhadap cost of equity capital ?

\section{TINJAUAN PUSTAKA, KERANGKA PEMIKIRAN DAN HIPOTESIS}

\subsection{Tinjauan Pustaka}

\subsubsection{Cost of Equity Capital}

Pengertian biaya modal (cost of equity capital) dalam literatur keuangan pertama kali didefiniskan oleh Modigliani dan Miller, 1958 yang menjelaskannya sebagai cost yang dikeluarkan untuk membiayai sumber pembelanjaan. Biaya modal dihitung atas dasar sumber dana jangka panjang yang tersedia bagi perusahaan. Ada empat sumber dana jangka panjang, yaitu : (1) hutang jangka panjang, (2) saham preferen, (3) saham biasa, (4) laba ditahan. Biaya hutang jangka panjang adalah biaya hutang sesudah pajak saat ini untuk mendapatkan dana jangka panjang melalui pinjaman. Biaya saham preferen adalah dividen saham preferen tahunan dibagi dengan hasil pejualan saham preferen.

Cost of equity capital (CEC) merupakan biaya peluang dari penggunaan dana untuk diinvestasikan dalam proyek baru. Konsep CEC erat hubungannya dengan tingkat keuntungan yang disyaratkan. CEC digunakan sebagai ukuran untuk pengambil keputusan dalam investasi, yaitu dengan cara membandingkan tingkat keuntungan yang disyaratkan dengan $C E C$. Lebih jauh lagi, jika perusahaan menghasilkan suatu tingkat pengembalian yang lebih tinggi dari $C E C$ maka pengembalian sisanya akan menyebabkan peningkatan nilai saham biasa perusahaan, dan selanjutnya, peningkatan kekayaan pemilik saham (Keown et al, 2000). Apabila tingkat pengembalian internal lebih kecil dari $C E C$, maka kekayaan pemilik saham akan menurun. Sebaliknya, bila tingkat pengembalian internal lebih besar dari $C E C$, maka kekayaan pemilik saham juga akan meningkat.

Biaya modal (cost of equity capital) merupakan biaya yang ditanggung perusahaan untuk memperoleh dana dari kegiatan reinvestasi termasuk didalamnya biaya pengungkapan yang dikeluarkan oleh perusahaan untuk kepentingan publik. (Agustini, 2011). Biaya modal adalah merupakan konsep yang dinamis yang dipengaruhi oleh beberapa faktor ekonomi. Struktur biaya modal didasarkan pada beberapa asumsi yang berkaitan dengan risiko dan pajak. Asumsi dasar yang digunakan dalam estimasi biaya modal adalah risiko bisnis dan risiko keuangan adalah tetap/relatif stabil (Utami, 2005).

\subsubsection{Corporate Social Responsibility}

Tanggung jawab sosial dan lingkungan (corporate social responsibility) pertama sekali dikemukakan oleh Howard Botton pada tahun 1953 dalam bukunya yang berjudul "The Social Responsibilities of $A$ Businessman" yang menjelaskan tentang tanggung jawab apa yang dapat diharapkan dalam sebuah perusahaan (Garriga \& Mele, 2004). Isitilah corporate social responsibility (CSR) mulai digunakan sejak tahun 1970-an dan semakin populer setelah kehadiran buku Cannibals With Forks : The Triple Bottom Line in 21st Century Business (1998), yang merupakan karya John Elkington yang mengembangkan tiga komponen penting sustainable development, yakni economic growth, environmental protection, dan social equity, yang digagas The World Commission on Environment and Development (WCED) dalam Brundtland Report (1987). Elkington mengemas corporate social responsibility ke dalam tiga fokus : 3P, singkatan dari profit, planet dan people. 
Pengertian corporate social responsiblity sekarang ini sangatlah beragam. Menurut The World Business Council for Sustainable Development (WBCSD), Corporate social responsibility adalah sebagai komitmen bisnis untuk memberikan kontribusi bagi pembangunan ekonomi berkelanjutan, melalui kerja sama dengan para karyawan serta perwakilan mereka, keluarga mereka, komunitas setempat maupun masyarakat umum untuk meningkatkan kualitas kehidupan dengan cara yang bermanfaat baik bagi bisnis sendiri maupun untuk pembangunan.

Rahman (2010) dan Untung (2008), konsep tanggung jawab sosial dan lingkungan perusahaan (Corporate social responsibility) tidak terlepas dari konteks waktu pada saat konsep ini berkembang dan berbagai faktor yang terjadi dilingkungan internal maupun eksternal perusahaan yang mempengaruhi perkembangan konsep CSR. Sementara itu, menurut Hadi (2011) bahwa tanggung jawab sosial dan lingkungan muncul dan berkembang sejalan dengan interalasi antara perusahaan dan masyarakat dan peradaban masyarakat. Semakin tinggi tingkat peradaban masyarakat, khususnya akibat perkembangan ilmu sehingga meningkatkan kesadaran dan perhatian lingkungan memunculkan tuntutan tanggung jawab perusahaan.

\subsubsection{Kepemilikan Institusional}

Menurut perspektif keagenan, keputusan struktur permodalan tidak hanya ditetapkan oleh faktor faktor internal dan eksternal seperti halnya pajak, financial distress costs maupun kondisi ekonomi makro tetapi juga oleh nilai nilai, tujuan, preferensi dan hasrat manajer serta pemegang saham (Sugiarto,2009). Struktur permodalan yang pada akhirnya berujung pada struktur kepemilikan perusahaan akhirnya menggambarkan komposisi kepemilikan saham dari suatu perusahaan. Struktur kepemilikan juga menjelaskan komitmen pemilik untuk mengelola dan menyelamatkan perusahaan.

Kepemilikan institusional adalah saham perusahaan yang dimiliki oleh institusi atau lembaga, seperti : perusahaan asuransi, bank, perusahaan investasi dan kepemilikan institusi lain. Cornett et al. (2006), menyatakan bahwa tindakan pengawasan perusahaan oleh kepemilikan institusional dapat mendorong manajer untuk lebih memfokuskan perhatiannya terhadap kinerja perusahaan sehingga akan mengurangi perilaku opportunistik atau mementingkan diri sendiri. Kepemilikan institusional memiliki kemampuan untuk mengendalikan pihak manajemen melalui proses monitoring secara efektif sehingga dapat mengurangi manajemen laba. Monitoring yang dilaksanakan oleh institusi akan menjamin kepentingan pemegang saham sehingga pengaruh kepemilikan institusional sebagai agen pengawas ditentukan melalui investasi mereka yang cukup besar dalam pasar modal.

Riyanto dan Ayu (2011) menjelaskan bahwa kepemilikan institusional berperan penting dalam pembuatan keputusan strategik, seperti keputusan melaksanakan tanggung jawab yang dapat meningkatkan nilai perusahaan pada jangka panjang. Namun demikian dampak dari kepemilikan institusional tidak selalu netral, saat investor institusional membuat keputusan kritis jangka pendek akibat keterbatasan pengetahuan mengenai perusahaan atau industri. Semakin besar tingkat kepemilikan saham oleh investor institusional, maka semakin efektif mekanisme kontrol terhadap kinerja manajemen untuk mencapai tujuan perusahaan untuk meningkatkan nilai perusahaan.

\subsubsection{Asimetri Informasi}

Teori agensi yang dikemukakan oleh Jensen dan Meckling pada tahun 1976 telah diungkapkan bahwa dalam dunia bisnis terjadi fenomena oportunis dan manusia sebagai individualistik cenderung untuk memenuhi utilitasnya secara maksimal. Hal ini mengakibatkan adanya distribusi informasi yang tidak merata antara majer (agent) dan investor atau pemegang saham (principal). Distribusi informasi yang tidak merata juga disebut sebagai asimetri informasi. Kondisi ketimpangan informasi ini juga dapat memberikan peluang kepada agent untuk memanipulasi pelaporan untuk memaksimalkan utilitasnya (Pratiwi et al., 2015).

Menurut Hartono (2010) asimetri informasi adalah kondisi yang menunjukan sebagian investor mempunyai informasi dan yang lainnya tidak memiliki. Sedangkan Hanafi (2014) menjelaskan bahwa konsep signaling dan asimetri informasi berkaitan erat, teori asimetri mengatakan bahwa pihak-pihak yang berkaitan dengan perusahaan tidak mempunyai informasi yang sama mengenai prospek dan risiko perusahaan, pihak tertentu mempunyai informasi lebih baik dibandingkan dengan pihak luar.

\subsubsection{Nilai Buku Ekuitas}

Dalam teori sinyal ini dikatakan bahwa perusahaan memiliki kewajiban mempunyai kewajiban untuk memberikan informasi laporan keuangan yang sebenar-benarnya pada pihak eksternal, yaitu pemilik perusahaan atau pemiliki saham perusahaan. Hal ini karena dengan memberikan informasi tersebut maka akan dapat menunjukkan bahwa kondisi perusahaan dalam keadaan baik sehingga akan meningkatkan nilai perusahaan dan menunjukkan bahwa perusahaan mempunyai nilai lebih/keunggulan kompetitif dari perusahaan lain. (Rianingtyas dan Trisnawati, 2017). Salah satu komponen informasi yang diperoleh dari laporan keuangan tersebut adalah nilai buku ekuitas, dimana nilai buku ekuitas akan menggambarkan jumlah ekuitas pemegang saham yang dilaporkan dan dikurangi oleh saham preferen dan dilaporkan dalam laporan posisi keuangan perusahaan. Nilai buku ekuitas juga merupakan nilai aset bersih yang dimiliki oleh perusahaan yaitu selisih dari total aset dikurang liabilitas yang dimiliki perusahaan. Nilai buku ekuitas menggambarkan informasi mengenai besarnya nilai 
sumber daya perusahaan dalam satuan moneter. (Fadliyah, 2008).

Nilai buku ekuitas akan memberikan manfaat karena digunakan untuk menghasilkan laba dari hasil aktivitas operasi perusahaan dimasa depan. Hal ini sesuai dengan konsep going-concern, yaitu dalam akuntansi, diasumsikan bahwa satuan usaha akan berlangsung terus atau memiliki umur yang tidak terbatas jika tidak ada tanda yang pasti di masa depan bahwa usaha tersebut akan dilikuidasi (Suwardjono, 2008).

\subsection{Kerangka Pemikiran}

Biaya ekuitas atau Cost of Equity banyak diartikan sebagai ekspektasi pemegang saham akan pengembalian dari modal yang sudah ditanamkan di perusahaan (Sirait dan Siregar, 2012). Dengan kata lain, Cost of Equity merupakan biaya yang dikeluarkan oleh suatu perusahaan atas modal yang telah ditanamkan oleh investor. Investor akan mensyaratkan rate of return yang diinginkan apabila menanamkan modalnya. Rate of return yang dipersyaratkan untuk suatu ekuitas adalah rate of return minimum yang diperlukan untuk menarik investor agar membeli atau menanam sekuritas. Rate of return merupakan suatu biaya oportunitas investor dalam melakukan investasi, yaitu apabila investasi telah dilakukan, maka investor harus meninggalkan return yang ditawarkan investor lain. Return yang hilang tersebut kemudian menjadi biaya oportunitas karena melakukan investasi dan kemudian biaya oportunitas inilah yang menjadi rate of return yang dipersyaratkan investor.

Penelitian ini menggunakan faktor pengungkapan CSR, kepemilikan institusional, dan asimetri informasi yang mempengaruhi cost of equity capital dengan nilai buku ekuitas sebagai faktor moderasi. Pengungkapan tentang aktivitas CSR pada laporan tahunan di Indonesia kebanyakan dilakukan secara sukarela oleh perusahaan. Salah satu motivasi perusahaan melakukan jenis pengungkapan CSR ini adalah untuk meningkatkan transparansi antara manajer dan pemangku kepentingan yang menggunakan laporan tahunan sehingga dapat menurunkan cost of equity capital. Agustini (2011), Suharsono dan Rahmasari (2013), Xu, Liu, dan Huang (2014), Jansen (2017), Rianingtyas dan Trisnawati (2017), Sukarti dan Suwarti (2018) mengungkapkan bahwa pengungkapan CSR terbukti berpengaruh terhadap cost of equity capital.

Masuknya suatu institusi sebagai pemegang saham akan membatasi peluang manajemen untuk melakukan manipulasi laba dalam laporan keuangan. Manajemen akan merasa khawatir kepada pemilik institusional apabila melakukan rekayasa laba karena ada banyak pihak yang mengawasi tindakannya. Kejujuran manajemen yang tidak mengelabui para pemegang saham akan direaksi positif oleh pasar saham yang berdampak pada meningkatkan permintaan sekuritas perusahaan dan meningkatkan harga pasar sehingga mengurangi cost of equity capital. Penelitian oleh oleh Sukarti dan Suwarti (2018) dan Babadi et.al (2018) menunjukkan bahwa kepemilikan institusional mampu meningkatkan kinerja pasar saham dan menekan resiko jika investor membeli saham perusahaan, sehingga dengan turunnya resiko menyebabkan perusahaan memiliki kelonggaran untuk tidak harus mengungkapkan semua informasi mengenai kondisi perusahaan sehingga dapat menurunkan cost of equity capital.

Asimetri informasi adalah ketimpangan informasi antara manajer dan pemegang saham, dimana manajer lebih mengetahui informasi internal dan prospek perusahaan dimasa yang akan datang dibanding pemegang saham, dimana dengan semakin kecilnya asimetri informasi diharapkan akan dapat menurunkan cost of equity capital. Astutik, et.al (2018), Admadianto (2017) dan Purwanto (2014) mengungkapkan bahwa asimetri informasi berpengaruh positif dan signifikan terhadap cost of equity capital.

Dalam penelitian ini pengaruh pengungkapan CSR, kepemilikan institusional dan asimetri informasi terhadap cost of equity capital dimoderasi oleh nilai buku ekuitas. Nilai buku ekuitas merupakan ukuran daya informasi akuntansi yang akan dipergunakan investor dalam keputusannya selain faktor laba. Nilai buku ekuitas sebagai gambaran nilai aktiva bersih pada satu lembar saham dengan nilai yang tinggi diharapkan dapat menurunkan cost of equity capital serta dapat mempengaruhi keputusan investor Semakin besar tingkat pengungkapan akuntansi yang dilakukan oleh perusahaan termasuk pengungkapan CSR, kepemilikan institusional yang besar, semakin kecilnya asimetri informasi serta nilai buku ekuitas yang baik, maka semakin rendah cost of equity capital. Yuniarta dan Agustini (2014) mengungkapkan bahwa nilai buku ekuitas sebagai variabel yang diproxikan dalam daya informasi akuntansi terbukti mempengaruhi hubungan pengungkapan corporate social responsibility (CSR) dengan cost of equity capital (CEC) yakni memperlemah pengaruh positif CSR terhadap CEC.

\subsection{Hipotesis}

Dari penjelasan di atas, maka dapat dirumuskan hipotesis dalam penelitian ini adalah sebagai berikut:

$\mathrm{H}_{1}$ : Corporate social responsibility berpengaruh terhadap cost of equity capital.

$\mathrm{H}_{2}$ : Kepemilikan institusional berpengaruh terhadap cost of equity capital.

$\mathrm{H}_{3}$ : Asimetri informasi berpengaruh terhadap cost of equity capital.

$\mathrm{H}_{4}$ : Nilai buku ekuitas memoderasi hubungan antara corporate social responsibility dan cost of equity capital.

H5 : Nilai buku ekuitas memoderasi hubungan antara kepemilikan institusional dan cost of equity capital. 
H6 : Nilai buku ekuitas memoderasi hubungan antara asimetri informasi dan cost of equity capital.

\section{METODOLOGI PENELITIAN}

\subsection{Objek dan Subjek Penelititan}

Objek yang akan diteliti dalam penelitian ini adalah variabel yang terkait dalam penelitian yaitu cost of equity capital yang merupakan variabel dependen, corporate social responsibility, kepemilikan institusional, dan asimetri informasi merupakan variabel independen, sedangkan nilai buku ekuitas sebagai variabel moderasi. Subjek Penelitian ini adalah perusahaan yang terdaftar pada LQ-45 di BEI periode $2015-2018$

\subsection{Jenis dan Sumber Data}

Jenis data yang digunakan dalam penelitian ini adalah data sekunder. Data yang digunakan dalam penelitian ini adalah dalam bentuk time series dan cross section yang diperoleh dari website www.idx.co.id,.

\subsection{Populasi dan Sampel}

Populasi penelitian ini adalah perusahaan LQ-45 yang listing dari tahun 2015 - 2018 di Bursa Efek Indonesia. Dari 45 perusahaan LQ-45, yang diambil menjadi sampel penelitian adalah 26 perusahaan. Teknik penarikan sampel penelitian adalah dengan menggunakan metode purposive sampling yaitu sampel dipilih atas dasar kesesuaian karakteristik sampel dengan kriteria pemilihan sampel yang ditentukan (Ghozali, 2014). Sampel yang dipilih dalam penelitian ini adalah perusahaan LQ-45 yang tercatat di BEI dengan kriteria sebagai berikut :

1. Perusahaan yang konsisten bergabung di LQ-45 berturut-turut selama periode 2015 - 2018.

2. Data laporan keuangan perusahaan tersedia berturut-turut untuk tahun pelaporan dari 2015 2018.

3. Perusahaan yang diteliti bukan lembaga keuangan yang tergabung di LQ-45 selama periode 2015 2018

Proses purposive sampling dalam penelitian dapat dilihat pada tabel 2 berikut ini:

Tabel 2. Proses Purposive Sampling Penelitian

\begin{tabular}{|c|l|c|}
\hline No & \multicolumn{1}{|c|}{ Purposive Sampling } & Jumlah \\
\hline 1 & Perusahaan LQ-45 di BEI & 45 \\
\hline \multirow{2}{*}{2} & $\begin{array}{l}\text { Dikurangi Perusahaan yang tidak } \\
\text { konsisten bergabung di LQ-45 } \\
\text { berturut-turut selama periode 2015 - } \\
2018\end{array}$ & (14) \\
\hline 3 & Perusahaan Non Lembaga Keuangan & $(5)$ \\
\hline & \multicolumn{1}{|c|}{ Jumlah } & 26 \\
\hline
\end{tabular}

Sumber: Bursa Efek Indonesia diolah, 2019

\subsection{Operasionalisasi Variabel}

Variabel dalam penelitian ini menggunakan variabel dependen yang diwakili oleh cost of equity capital, sedangkan vaiabel independen adalah coroporate social responsibility, kepemilikan institusional, asimetri informasi sedangkan nilai buku ekuitas sebagai variabel moderasi.

\subsection{Metode Analisis Data}

Metode analisis data untuk membuktikan hipotesis pertama sampai hipotesis keenam dalam penelitian ini menggunakan analisis regresi data panel. Data panel adalah data yang memiliki jumlah cross section dan jumlah time series. Data dikumpulkan dalam suatu rentang waktu terhadap banyak individu. Alasan penelitian menggunakan data panel, karena terdapat beberapa keunggulan dari penggunaan data panel dibandingkan dengan data time series dan cross section.

Metode analisis data untuk membuktikan hipotesis pertama sampai hipotesis keenam dalam penelitian ini menggunakan analisis regresi data panel. Data panel adalah data yang memiliki jumlah cross section dan jumlah time series. Data dikumpulkan dalam suatu rentang waktu terhadap banyak individu. Alasan penelitian menggunakan data panel, karena terdapat beberapa keunggulan dari penggunaan data panel dibandingkan dengan data time series dan cross section.

Model yang digunakan dalam penelitian ini disajikan dalam persamaan sebagai berikut:

$Y=\alpha+\beta_{1} X_{1}+\beta_{2} X_{2}+\beta_{3} X_{3}+\beta_{4} X_{4}+\beta_{5} X_{1} X_{4}+\beta_{6} X_{2} X_{4}+$ $\mathrm{B}_{7} \mathrm{X}_{3} \mathrm{X}_{4}+\mathrm{e}$

\section{Keterangan:}

$\mathrm{Y} \quad=$ Cost of equity capital.

A $=$ Konstanta.

$\beta_{1}-\beta_{7}=$ Koefisien Regresi.

$\mathrm{X}_{1}=$ Corporate social responsibility.

$\mathrm{X}_{2}=$ Kepemilikan Institusional.

$\mathrm{X}_{3}=$ Asimetri Informasi.

$\mathrm{X}_{4}=$ Nilai Buku Ekuitas.

$\mathrm{X}_{1} \mathrm{X}_{4}=$ Interaksi antara corporate social responsibility dengan nilai buku ekuitas yang diukur berdasarkan nilai interaksi antara $\mathrm{X}_{1}$ dan $\mathrm{X}_{4}$.

$\mathrm{X}_{2} \mathrm{X}_{4}=$ Interaksi antara kepemilikan institusional dengan nilai buku ekuitas yang diukur berdasarkan nilai interaksi antara $\mathrm{X}_{2}$ dan $\mathrm{X}_{4}$.

$\mathrm{X}_{3} \mathrm{X}_{4}=$ Interaksi antara asimetri informasi dengan nilai buku ekuitas yang diukur berdasarkan nilai interaksi antara $\mathrm{X}_{3}$ dan $\mathrm{X}_{4}$.

e $=$ Error

\subsubsection{Pemilihan Metode Estimasi Analisis Data Panel}

Analisis data panel dilakukan menggunakan tiga pendekatan untuk mengestimasi, oleh karena itu perlu melakukan pengujian untuk menentukan mana diantara ketiga pendekatan tersebut yang paling sesuai dengan 
data yang digunakan. Pendekatan analisis data panel antara lain dengan metode common effect, fixed effect dan random effect.

1. Pengujian Antara Metode Common Effect atau Metode Fixed Effect

Untuk menguji model terbaik antara menggunakan metode common effect atau dengan menggunakan metode individual effect (yang diawali oleh model fixed effect) menggunakan redundant fixed effect test terlebih dahulu membuat hipotesis:

$H_{0}: \alpha 1=\alpha 2=\alpha 3=\ldots=\alpha \mathrm{i}$, Common Effect

$H_{a}: \alpha 1 \neq \alpha 2 \neq \alpha 3 \neq \ldots \neq \alpha \mathrm{i}$, Individual Effect

Untuk pengambilan keputusan apakah $H_{0}$ atau $H_{a}$ yang diterima maka bandingkan hasil $F_{\text {test }}$ dengan $F_{\text {table. }} F_{\text {table }}$ dicari pada $\alpha$ tertentu untuk $m$ numerator df dan (n-k) dominator df. Jika $F_{\text {test }}$ lebih besar dari $F_{\text {table }}$ maka $H_{O}$ ditolak sehingga $H_{a}$ diterima artinya model yang digunakan adalah individual effect (fixed effect). Sebaliknya jika $F_{\text {test }}$ lebih kecil dari $F_{\text {table }}$ maka $H_{0}$ diterima sehingga $H_{a}$ ditolak yang artinya model yang digunakan adalah common effect (Gujarati, 2003).

2. Pengujian Antara Motode Fixed Effect atau Metode Random Effect

Pengambilan keputusan apakah menggunakan fixed effect atau random effect dilakukan dengan menggunakan haustman test. Dilihat dengan menggunakan nilai probability ( $p$-value) sehingga keputusan pemilihan kedua model tersebut akan dapat ditentukan secara statistik. Sebelum melakukan pengujian yang pertama kita membuat hipotesis dulu:

$\mathrm{H}_{0}$ : Ada gangguan antar individu (random effect)

$\mathrm{H}_{\mathrm{a}}$ : Tidak ada gangguan antar individu (fixed effect)

Pengambilan keputusan didasarkan pada membandingkan hasil haussman test ini, dimana jika $p$-value lebih kecil 0,05 , maka $\mathrm{H}_{0}$ diterima dan $\mathrm{H}_{\mathrm{a}}$ ditolak, berarti analisis yang digunakan yaitu metode random effect. Sebaliknya jika $p$ value lebih besar dari 0,05 , maka $\mathrm{H}_{0}$ ditolak dan $\mathrm{H}_{\mathrm{a}}$ diterima, berarti analisis yang digunakan yaitu dengan metode fixed effect.

3. Pengujian Antara Metode Common Effect atau Metode Random Effect

Pengambilan keputusan apakah menggunakan common effect atau random effect dilakukan dengan menggunakan langrange multiplier (LM) test. Dilihat dengan menggunakan nilai probability ( $p$-value) sehingga keputusan pemilihan kedua model tersebut akan dapat ditentukan secara statistik. Sebelum melakukan pengujian yang pertama kita membuat hipotesis dulu:
$\mathrm{H}_{0}$ : Menerima penggunaan metode common effect

$\mathrm{H}_{\mathrm{a}}$ : Menerima penggunaan metode random effect

Pengambilan keputusan didasarkan pada membandingkan hasil LM-Test, dimana jika $p$ value lebih kecil 0,05 , maka $\mathrm{H}_{0}$ ditolak dan $\mathrm{H}_{\mathrm{a}}$ diterima, berarti analisis yang digunakan yaitu metode random effect. Sebaliknya jika p-value lebih besar dari 0,05 , maka $\mathrm{H}_{0}$ diterima dan $\mathrm{H}_{\mathrm{a}}$ ditolak, berarti analisis yang digunakan yaitu dengan metode common effect.

\subsubsection{Pengujian Hipotesis}

Pengujian parameter individual (uji Statistik t) digunakan untuk menjawab rumusan masalah pertama sampai keenam. Uji ini dimaksudkan untuk melihat apakah variabel bebas mempunyai pengaruh terhadap variabel tak bebas dengan asumsi variabel bebas lainnya konstan (Ghozali, 2011).

Keterangan:

$$
\mathbf{t}=\frac{\boldsymbol{\beta}_{\mathrm{i}}}{\boldsymbol{s}_{\boldsymbol{\beta}_{\mathrm{i}}}}
$$

$\beta_{i}$ : Koefisien regresi untuk masing-masing variabel bebas

$S \beta i$ : Standard error dari $\beta_{i}$

Dari perhitungan tersebut maka selanjutnya membandingkan antara nilai $t_{\text {hitung }}$ dengan $t_{\text {tabel }}$ pada tingkat keyakinan $95 \%(\alpha=0,05)$, dengan kriteria keputusan:

Jika $\mathrm{t}_{\text {hitung }}<\mathrm{t}_{\text {tabel }}: \mathrm{H}_{0}$ diterima atau $\mathrm{H}_{\alpha}$ ditolak

Jika thitung $\geq t_{\text {tabel }}: \mathrm{H}_{\alpha}$ diterima atau $\mathrm{H}_{0}$ ditolak

Alternatif lain yang dapat digunakan untuk menerima atau menolak hipotesis yang dirumuskan, yaitu dengan melihat signifikansi lebih kecil dari 0,05 maka $\mathrm{H}_{0}$ ditolak atau $\mathrm{H}_{\alpha}$ diterima artinya secara parsial variabel bebas tersebut bepengaruh secara signifikan terhadap variabel terikat (Ghozali, 2011).

\section{HASIL DAN PEMBAHASAN}

\subsection{Hasil Penelitian}

\subsubsection{Deskripsi Data}

Variabel yang diteliti dalam penelitian ini antara lain yaitu: corporate social responsibillity $\left(\mathrm{X}_{1}\right)$, kepemilikan institusional $\left(\mathrm{X}_{2}\right)$, asimetri informasi $\left(\mathrm{X}_{3}\right)$, nilai buku ekuitas $\left(\mathrm{X}_{4}\right)$, dan cost of equity capital $(\mathrm{Y})$. Analisis deksriptif dilakukan untuk melihat gambaran umum mengenai variabel-variabel yang diteliti dilihat dari nilai maksimum dan minimum, rata-rata dan standar deviasi. Hasil analisis deskriptif disajikan sebagai berikut: 


\section{Tabel 3. Statistik Deskriptif Variabel Corporate Social Responsibility, Kepemilikan Instutional, Asimetri Informasi, Nilai buku ekuitas dan Cost of Equity Capital}

\begin{tabular}{|l|c|c|c|c|c|}
\hline & $\mathrm{X} 1$ & $\mathrm{X} 2$ & $\mathrm{X} 3$ & $\mathrm{X} 4$ & $\mathrm{Y}$ \\
\hline Rata-rata & 47,99 & 59,20 & 0,15 & $3.247,28$ & 12,58 \\
\hline Nilai tengah & 48,89 & 58,49 & 0,14 & $1.761,10$ & 11,41 \\
\hline Tertinggi & 83,33 & 84,99 & 0,27 & $23.456,98$ & 32,09 \\
\hline Terendah & 14,44 & 17,48 & 0,07 & 233.35 & 1,19 \\
\hline $\begin{array}{l}\text { Standar } \\
\text { deviasi }\end{array}$ & 16,413 & 14,544 & 0,044 & $4.505,79$ & 6,138 \\
\hline Observasi (N) & 104 & 104 & 104 & 104 & 104 \\
\hline
\end{tabular}

Sumber: Hasil pengolahan data, 2019

Berdasarkan tabel di atas dapat dijelaskan hal-hal sebagai berikut:

1. Pengungkapan corporate social responsibility (CSR) yaitu jumlah informasi yang diungkap dalam laporan tahunan perusahaan yang berhubungan dengan pelaksanaan corporate social responsibility perusahaan. Variabel ini diukur menggunakan instrumen dari Global Reporting Initiative (GRI) Versi G4 dengan memberikan skor (1) jika perusahaan menyajikan pengungkapan sosial, dan skor (0) jika tidak menyajikan pengungkapan sosial. Selanjutnya, skor dari setiap item dijumlahkan untuk memperoleh keseluruhan skor untuk setiap perusahaan. Pada perusahaan yang terdaftar dalam indeks LQ-45, rata-rata pengungkapan CSR yaitu sebesar 47,99 dengan nilai terendah sebesar 14,44 dan nilai tertinggi sebesar 83,3.

2. Kepemilikan institusional merupakan proporsi kepemilikan saham yang dimiliki oleh institusi. Pada perusahaan yang terdaftar dalam indeks LQ-45 periode tahun 2015 - 2018, rata-rata kepemilikan institusional yaitu sebesar 59,20 dengan nilai terendah sebesar 17,48 dan nilai tertinggi sebesar 84,99 .

3. Asimetri informasi merupakan variabel yang menunjukkan kepada kesenjangan informasi antara pihak principal dengan manjemen perusahaan. Nilai asimetri informasi diukur menggunakan nilai relatif bid-ask spread. Pada perusahaan yang terdaftar dalam indeks LQ-45, rata-rata asimetri informasi yaitu sebesar 0,15 dengan nilai terendah sebesar 0,07 dan nilai tertinggi sebesar 0,27.

4. Nilai buku ekuitas merupakan ukuran kualitas laporan keuangan dilihat dari daya indormasi angka-angka yang disajikan dalam laporan keuangan. Nilai buku ekuitas diukur menggunakan book value of equity (nilai buku ekuitas). Pada perusahaan yang terdaftar dalam indeks LQ-45, rata-rata nilai buku ekuitas yaitu sebesar 3.247,28 dengan nilai terndah sebesar 233,35 dan nilai tertinggi sebesar 23.456,98.

5. Cost of equity capital (CEC) dalam penelitian ini yaitu biaya yang dikeluarkan oleh perusahaan untuk menyediakan informasi bagi publik. Pengukuran CEC pada penelitian ini menggunakan pendekatan Capital Asset Pricing Model (CAPM). Pendekatan CAPM menggambarkan hubungan risiko dan return yang lebih sederhana dengan menggunakan variabel beta untuk menggambarkan risiko. Pada perusahaan yang terdaftar dalam indeks LQ-45, nilai rata-rata cost of equity capital sebesar 12,58 dengan nilai terendah sebesar 1,19 dan nilai tertinggi sebesar 32,09 .

\subsubsection{Pemilihan Model Analisis Data Panel}

\section{Pemilihan Antara Model Common Effect atau} Model Fixed Effect

Untuk menguji model terbaik antara menggunakan model common effect atau dengan menggunakan model fixed effect, bisa menggunakan uji Chow atau redundant fixed effect test. Sebelum dilakukan redundant fixed effect test terlebih dahulu dirumuskan hipotesis sebagai berikut:

$\mathrm{H}_{0}: \alpha 1=\alpha 2=\alpha 3=\ldots .=\alpha \mathrm{i}$, Common Effect (Common Effect)

$\mathrm{H}_{\mathrm{a}}: \alpha 1 \neq \alpha 2 \neq \alpha 3 \neq \ldots \neq \neq \alpha \mathrm{i}$, Individual Effect (Fixed Effect)

Pemilihan model estimasi common effect dan fixed effect dilakukan dengan menggunakan redundant fixed effect test dengan hasil sebagai berikut:

Tabel 4. Redundant Fixed Effect Test

Redundant Fixed Effects Tests

Equation: Untitled

Test cross-section fixed effects

\begin{tabular}{|c|c|c|c|}
\hline Effects Test & Statistic & d.f. & Prob. \\
\hline Cross-section F & 2.195832 & $(25,71)$ & 0.0052 \\
\hline Cross-section Chi-square & 59.568559 & 25 & 0.0001 \\
\hline
\end{tabular}

Sumber: Hasil pengolahan data, 2019

Berdasarkan tabel 4 di atas didapatkan nilai Probability Cross-section $F=0,0052$ lebih kecil dari taraf signifikansi 0,05 . Hal ini berarti $\mathrm{H}_{0}$ diterima dan Ha ditolak. Dengan demikian pada model data panel terdapat gangguan individu atau dengan kata lain bahwa analisis sebaiknya menggunakan model fixed effect daripada model common effect.

\section{Pemilihan Antara Model Fixed Effect atau Model Random Effect}

Pengambilan keputusan apakah menggunakan model fixed effect atau menggunakan model random effect dilakukan dengan menggunakan haussman test. Pengambilan keputusan dengan membandingkan nilai $p$-value dengan taraf signifikansi $\alpha=0,05$, jika $p$-value lebih kecil dari 0,05 maka analisis yang digunakan sebaiknya model fixed effect. Sebaliknya jika $p$-value lebih besar dari 0,05 maka analisis sebaiknya menggunakan model random effect (Gujarati, 2003). Hasil pengujian haussman test adalah sebagai berikut: 
Pengaruh Corporate Social Responsibility, Kepemilikan Institusional dan Asimetri Informasi Terhadap Cost of Equity Capital Dengan Nilai Buku Ekuitas Sebagai Variabel Moderasi (Studi Pada Perusahaan Non Lembaga Keuangan Dalam Indeks LQ-45 Tahun 2015 - 2018) (Edison Vain S, Afrizal dan Yudi)

Tabel 5. Hasil Haussman Test

Correlated Random Effects - Hausman Test

Equation: Untitled

Test cross-section random effects

\begin{tabular}{lrrr}
\hline \hline Test Summary & Chi-Sq. Statistic & $\begin{array}{r}\text { Chi-Sq. } \\
\text { d.f. }\end{array}$ & Prob. \\
\hline \hline Cross-section random & 28.483930 & 7 & 0.0002 \\
\hline \hline Sumber: Hasil pengolahan data, 2019
\end{tabular}

Berdasarkan tabel 5 di atas dapat dilihat bahwa $p$ value yaitu 0,0002 lebih kecil dari 0,05 . Hal ini berarti $\mathrm{H}_{0}$ ditolak dan $\mathrm{H}_{\mathrm{a}}$ diterima, yang berarti asumsi penerimaan model fixed effect diterima dan menolak asumsi penggunaan model random effect. Dengan demikian, berdasarkan hasil Haussman test menunjukkan bahwa model yang sebaiknya digunakan adalah model fixed effect.

\section{Pemilihan Antara Model Common Effect atau Model Random Effect}

Pemilihan model antara common effect dan fixed effect menggunakan metode redundant fixed effect test menunjukkan bahwa model yang sebaiknya digunakan adalah model fixed effect. Sementara itu, berdasarkan hasil haussman test menunjukkan bahwa model analisis yang sebaiknya digunakan juga adalah model fixed effect. Oleh karena itu, tidak lagi diperlukan perbandingan antara common effect dan random effect, karena dari hasil redundant fixed effect test dan haussman test sudah jelas bahwa model yang terbaik digunakan adalah fixed effect.

\subsubsection{Analisis Data Panel dengan Metode Fixed Effect}

Hasil analisis data panel dengan model estimasi common effect digambarkan dalam tabel berikut ini:

\section{Tabel 6. Hasil Analisis Regresi Data Panel Menggunakan Model Fixed Effect}

Dependent Variable: Y

Method: Panel EGLS (Cross-section weights)

Sample: 20152018

Periods included: 4

Cross-sections included: 26

Total panel (balanced) observations: 104

Linear estimation after one-step weighting matrix

White diagonal standard errors \& covariance (d.f. corrected) squared

S.E. of

regression $\quad 4.554556$ Sum squared resid

F-statistic $\quad 16.23455$ Durbin-Watson stat

Prob (F-

statistic)

0.000000

Sumber: Hasil pengolahan data, 2019

Berdasarkan tabel 6 di atas, dari koefisien regresi dibentuk persamaan regresi sebagai berikut:

$\mathrm{Y}=8,355715-0,047738 \mathrm{X}_{1}-0,186653 \mathrm{X}_{2}+$ $148,1248 \mathrm{X}_{3}-0,008985 \mathrm{X}_{4}+0,0000235 \mathrm{X}_{1} \mathrm{X}_{4}+$ $0,000111 \mathrm{X}_{2} \mathrm{X}_{4}-0,004525 \mathrm{X}_{3} \mathrm{X}_{4}$

Berdasarkan tabel di atas dapat dirumuskan halhal sebagai berikut:

1. Nilai konstan $(\mathrm{c})=8,355715$, berarti bahwa pada saat corporate social responsibillity, kepemilikan institusional, asimetri informasi, nilai buku ekuitas, dan semua variabel moderasi sama dengan 0 , maka cost of equity capital bernilai positif sebesar 8,355715 satuan.

2. Koefisien regresi variabel corporate social responsibillity bernilai negatif sebesar 0,047738 , hal ini memperlihatkan bahwa apabila pengungkapan corporate social responsibillity pada perusahaan LQ-45 di BEI tahun 2015 - 2018 mengalami peningkatan sebesar $1 \%$, maka nilai cost of equity capital akan mengalami penurunan sebesar 0,047738 satuan pada saat variabel yang lain diasumsikan konstan.

3. Koefisien regresi variabel kepemilikan institusional bernilai negatif sebesar 0,186653 , hal ini memperlihatkan bahwa apabila kepemilikan institusional pada perusahaan LQ-45 di BEI tahun 2015 - 2018 meningkat sebesar 1\%, maka cost of equity capital cenderung mengalami penurunan sebesar 0,186653 satuan pada saat variabel yang lain diasumsikan konstan.

4. Koefisien regresi variabel asimetri informasi bernilai positif sebesar 148,1248, hal ini memperlihatkan bahwa apabila nilai asimetri informasi perusahaan LQ-45 di BEI tahun 2015 2018 meningkat sebesar 1 satuan, maka akan terjadi peningkatan cost of equity capital sebesar 148,1248 satuan pada saat variabel yang lain diasumsikan konstan.

\begin{tabular}{|c|c|c|c|c|}
\hline Variable & Coefficient & Std. Error & $\mathrm{t}$-Statistic & $\begin{array}{l}\text { satuan pada saat variabel yang lain diasumsikan } \\
\text { Prob. } \\
\text { konstan. }\end{array}$ \\
\hline $\mathrm{C}$ & 8.355715 & 9.132569 & 0.914936 & 0.3533 Koefisien regresi variabel nilai buku ekuitas bernilai \\
\hline $\mathrm{X} 1$ & -0.047738 & 0.129 & -0.368007 & tif sebesar 0,008985 , hal ini memperlihatkan \\
\hline $\mathrm{X} 2$ & -0.186653 & 0.132 & $\begin{array}{r}-1.409345 \\
11.9477\end{array}$ & 0.1631 bahwa apabila nilai buku ekuitas LQ-45 di BEI \\
\hline $\mathrm{X} 3$ & 148.1248 & 12 & 77 & $\begin{array}{l}0.0000 \text { bahwa apabila nilai buku ekuitas LQ-45 di BEI } \\
0.0019 \text { tahun } 2015 \text { - } 2018 \text { meningkat sebesar } 1 \text { satuan, }\end{array}$ \\
\hline $\begin{array}{c}\mathrm{X} 4 \\
\mathrm{X} 1 \mathrm{X} 4\end{array}$ & $\begin{array}{r}-0.008985 \\
2.35 \mathrm{E}-05\end{array}$ & $\begin{array}{l}0.002789 \\
1.60 \mathrm{E}-05\end{array}$ & $\begin{array}{r}-3.221967 \\
1.471671\end{array}$ & $\begin{array}{l}0.0019 \text { tahun } 2015 \text { - } 2018 \text { meningkat sebesar I satua } \\
0.1455 \text { maka akan teriadi penurunan cost of equity canit }\end{array}$ \\
\hline $\begin{array}{l}\mathrm{X} 1 \mathrm{X} 4 \\
\mathrm{X} 2 \mathrm{X} 4\end{array}$ & 0. & & 3.546 & $\begin{array}{l}\text {.145maka akan terjadi penurunan cost of equity capttal } \\
0.0007 \text { sebesar } 0.008985 \text { satuan nada sat variabel vang }\end{array}$ \\
\hline $\mathrm{X} 3 \mathrm{X} 4$ & -0.004525 & 0.001759 & -2.572663 & 0.0122 lain diasumsikan konstan. \\
\hline
\end{tabular}

\begin{tabular}{ccl}
\hline \hline R-squared & 0.879764 & Mean dependent var \\
Adjusted R- & 0.825573 & S.D. dependent var
\end{tabular}

6. Koefisien regresi variabel interaksi antara nilai buku 23.00440 ekuitas dengan corporate social responsibillity 23.08444bernilai positif sebesar 0,0000235 , hal ini 
memperlihatkan bahwa apabila interaksi antara nilai buku ekuitas dengan pengungkapan corporate social responsibillity pada perusahaan LQ-45 di BEI tahun 2015 - 2018 mengalami peningkatan sebesar 1 satuan, maka nilai cost of equity capital akan mengalami peningkatan sebesar 0,0000235 satuan pada saat variabel yang lain diasumsikan konstan.

7. Koefisien regresi variabel interaksi antara nilai buku ekuitas dengan kepemilikan institusional bernilai positif sebesar 0,000111, hal ini memperlihatkan bahwa apabila interaksi antara nilai buku ekuitas dengan kepemilikan institusional pada perusahaan LQ-45 di BEI tahun 2015 - 2018 meningkat sebesar $1 \%$, maka cost of equity capital cenderung mengalami peningkatan sebesar 0,000111 satuan pada saat variabel yang lain diasumsikan konstan.

8. Koefisien regresi variabel interaksi antara nilai buku ekuitas dengan asimetri informasi bernilai negatif sebesar 0,004525, hal ini memperlihatkan bahwa apabila interaksi antara nilai buku ekuitas dengan nilai asimetri informasi perusahaan LQ-45 di BEI tahun 2015 - 2018 meningkat sebesar 1 satuan, maka akan terjadi peningkatan cost of equity capital sebesar 0,004525 satuan pada saat variabel yang lain diasumsikan konstan.

\subsubsection{Hasil Pengujian Hipotesis}

Pengujian hipotesis dilakukan untuk melihat signifikansi pengaruh corporate social responsibillity, kepemilikan institusional, dan asimetri informasi, terhadap cost of equity capital dan kemampuan variabel nilai buku ekuitas dalam memoderasi pengaruh corporate social responsibillity, kepemilikan institusional, dan asimetri informasi, terhadap cost of equity capital. Pengujian hipotesis dilakukan dengan menggunakan uji t. Kriteria keputusan dilihat nilai thitung dari setiap koefisien regresi masing-masing variabel independen dibandingkan dengan $t_{\text {tabel }}$ pada taraf signifikansi 0,05. Hasil pengujian hipotesis yaitu sebagai berikut:

1. Pengujian pengaruh corporate social responsibillity terhadap cost of equity capital

Pada variabel corporate social responsibillity, $t_{\text {hitung }}$ bernilai negatif sebesar 0,368007 , sedangkan $t_{\text {tabel }}$ pada taraf signifikansi 0,05 dengan df $=\mathrm{N}-\mathrm{k}=104$ $-7=97$ sebesar $1,985, \mathrm{t}_{\text {hitung }}<\mathrm{t}_{\text {tabel }}$, yang berarti bahwa $\mathrm{H}_{0}$ diterima dan dan $\mathrm{H}_{\mathrm{a}}$ ditolak, dengan demikian corporate social responsibillity tidak berpengaruh terhadap cost of equity capital pada perusahaan LQ-45 di BEI tahun 2015 - 2018.

2. Pengujian pengaruh kepemilikan institusional terhadap cost of equity capital

Pada variabel kepemilikan institusional, $t_{\text {hitung }}$ bernilai negatif sebesar 1,409345 , sedangkan $t_{\text {tabel }}$ pada taraf signifikansi 0,05 dengan $\mathrm{df}=\mathrm{N}-\mathrm{k}=104$ $-7=97$ sebesar 1,985 , $\mathrm{t}_{\text {hitung }}<\mathrm{t}_{\text {tabel }}$, yang berarti bahwa $\mathrm{H}_{0}$ diterima dan dan $\mathrm{H}_{\mathrm{a}}$ ditolak, dengan demikian kepemilikan institusional tidak berpengaruh terhadap cost of equity capital pada perusahaan LQ-45 di BEI tahun 2015 - 2018.

3. Pengujian pengaruh asimetri informasi terhadap cost of equity capital

Pada variabel asimetri informasi, $t_{\text {hitung }}$ bernilai positif sebesar 11,84477 , sedangkan $t_{\text {tabel }}$ pada taraf signifikansi 0,05 dengan $\mathrm{df}=\mathrm{N}-\mathrm{k}=104-7=97$ sebesar 1,985 , $t_{\text {hitung }}>\mathrm{t}_{\text {tabel }}$, yang berarti bahwa $\mathrm{H}_{0}$ ditolak dan dan $\mathrm{H}_{\mathrm{a}}$ diterima, dengan demikian asimetri informasi berpengaruh positif terhadap cost of equity capital pada perusahaan LQ-45 di BEI tahun 2015 - 2018.

4. Pengujian pengaruh nilai buku ekuitas dalam memoderasi hubungan antara corporate social responsibility dengan cost of equity capital

Pada variabel interaksi antara nilai buku ekuitas dan corporate social responsibility, $\mathrm{t}_{\text {hitung }}$ bernilai positif sebesar 1,471671, sedangkan $t_{\text {tabel }}$ pada taraf signifikansi 0,05 dengan $\mathrm{df}=\mathrm{N}-\mathrm{k}=104-7=97$ sebesar 1,985 , $\mathrm{t}_{\text {hitung }}<\mathrm{t}_{\text {tabel }}$, yang berarti bahwa $\mathrm{H}_{0}$ diterima dan dan $\mathrm{H}_{\mathrm{a}}$ ditolak, dengan demikian nilai buku ekuitas tidak mampu memoderasi hubungan antara corporate social responsibility dengan cost of equity capital pada perusahaan LQ-45 di BEI tahun 2015 - 2018.

5. Pengujian pengaruh nilai buku ekuitas dalam memoderasi hubungan antara kepemilikan institusional dengan cost of equity capital

Pada variabel interaksi antara nilai buku ekuitas dan kepemilikan institusional, $t_{\text {hitung }}$ bernilai positif sebesar 3,546839, sedangkan $t_{\text {tabel }}$ pada taraf signifikansi 0,05 dengan $\mathrm{df}=\mathrm{N}-\mathrm{k}=104-7=97$ sebesar 1,985 , thitung $<\mathrm{t}_{\text {tabel }}$, yang berarti bahwa $\mathrm{H}_{0}$ ditolak dan dan $\mathrm{H}_{\mathrm{a}}$ diterima, dengan demikian nilai buku ekuitas mampu memperkuat hubungan antara kepemilikan institusional dengan cost of equity capital pada perusahaan LQ-45 di BEI tahun 2015 2018.

6. Pengujian pengaruh nilai buku ekuitas dalam memoderasi hubungan antara asimetri informasi dengan cost of equity capital

Pada variabel interaksi antara nilai buku ekuitas dan asimetri informasi, $t_{\text {hitung }}$ bernilai negatif sebesar 2,572663, sedangkan $t_{\text {tabel }}$ pada taraf signifikansi 0,05 dengan $\mathrm{df}=\mathrm{N}-\mathrm{k}=104-7=97$ sebesar $1,985, t_{\text {hitung }}<\mathrm{t}_{\text {tabel }}$, yang berarti bahwa $\mathrm{H}_{0}$ ditolak dan dan $\mathrm{H}_{\mathrm{a}}$ diterima, dengan demikian nilai buku ekuitas mampu memperkuat hubungan antara asimetri informasi dengan cost of equity capital pada perusahaan LQ-45 di BEI tahun 2015 - 2018.

Besarnya pengaruh corporate social responsibillity, kepemilikan institusional, asimetri informasi, nilai buku ekuitas, dan semua variabel moderasi terhadap cost of equity capital dapat dilihat pada nilai koefisien determinasi (adjusted $R^{2}$ ) dalam tabel 4.4 di atas. Dari tabel 4.4 dapat dilihat bahwa besarnya koefisien determinasi (Adjusted $R^{2}$ ) yaitu sebesar 0,825573 . Besarnya pengaruh yaitu $0,825573 \mathrm{x}$ $100 \%=82,5573 \%$, dan sisanya sebesar $17,4427 \%$ 
Pengaruh Corporate Social Responsibility, Kepemilikan Institusional dan Asimetri Informasi Terhadap Cost of Equity Capital Dengan Nilai Buku Ekuitas Sebagai Variabel Moderasi (Studi Pada Perusahaan Non Lembaga Keuangan Dalam Indeks LQ-45 Tahun 2015 - 2018) (Edison Vain S, Afrizal dan Yudi)

dipengaruhi oleh faktor lain yang tidak termasuk dalam variabel penelitian.

\subsection{Pembahasan}

4.2.1. Pengaruh Corporate Social Responsibillity terhadap Cost of Equity Capital pada Perusahaan LQ-45 di Bursa Efek Indonesia Tahun 20152018

Teori sinyal menjelaskan bahwa perusahaan memiliki kewajiban untuk memberikan informasi laporan keuangan yang sebenar-benarnya pada pihak eksternal, yaitu pemilik perusahaan atau pemiliki saham perusahaan. Hal ini karena dengan memberikan informasi tersebut maka akan dapat menunjukkan bahwa kondisi perusahaan dalam keadaan baik sehingga akan meningkatkan nilai perusahaan dan menunjukkan bahwa perusahaan mempunyai nilai lebih/keunggulan kompetitif dari perusahaan lain. Berkaitan dengan hubungan teori sinyal dengan pengungkapan corporate social responsibility bahwa pengungkapan CSR merupakan salah satu cara untuk memberikan sinyal baik kepada para investor mengenai kondisi perusahaan untuk meningkatkan kredibilitas perusahaan dan memaksimalisasi nilai saham perusahaan sehingga dengan kepercayaan investor yang tinggi tersebut akan hal tersebut akan dapat mempengaruhi cost of equity capital yang akan dikeluarkan oleh perusahaan.

Penelitian ini memperlihatkan bahwa corporate social responsibillity tidak berpengaruh terhadap cost of equity capital pada perusahaan LQ-45 di BEI tahun 2015 - 2018. Hal ini dibuktikan dari hasil pengujian hipotesis yang menunjukkan bahwa thitung bernilai negatif dan nilainya lebih kecil dari $t_{\text {tabel }}$ pada taraf signifikansi 0,05 . Dengan demikian corporate social responsibillity bukan merupakan prediktor yang baik untuk menjelaskan cost of equity capital. Penelitian ini mendukung hasil penelitian sebelumnya yang dilakukan oleh Sirait dan Siregar (2012) yang mengungkapkan bahwa tidak ditemukan adanya hubungan signifikan antara pengungkapan CSR dengan perubahan biaya modal ekuitas tahun berikutnya.

Penelitian ini juga membantah penelitian sebelumnya yang dilakukan oleh Sukarti dan Suwarti (2018) yang mengungkapkan bahwa pengungkapan CSR berpengaruh positif terhadap Cost of Equity Capital. Sementara itu, penelitian ini juga menunjukkan hasil yang berbeda dengan penelitian sebelumnya yang dilakukan oleh Razali et.al (2017), Jansen (2017), dan $\mathrm{Xu}$ et.al (2014) dan Agustini (2011) yang mengungkapkan bahwa perusahaan dengan skor CSR yang lebih tinggi memiliki biaya modal ekuitas yang jauh lebih rendah. Secara khusus, penelitian ini menemukan bahwa investasi dalam meningkatkan CSR terhadap investor memberikan kontribusi terbesar untuk mengurangi biaya pendanaan ekuitas perusahaan.
4.2.2. Pengaruh Kepemilikan Institusional terhadap Cost of Equity Capital pada Perusahaan LQ-45 di Bursa Efek Indonesia Tahun 2015-2018

Teori agency menjelaskan bahwa hubungan antara manajer (agent) dengan pemegang saham (principal) sering menemukan konflik dikarenakan manusia adalah makhluk ekonomi yang mempunyai sifat dasar mementingkan kepentingan dirinya sendiri. Pemegang saham perusahaan (principal) dengan jumlah kepemilikannya banyak dimiliki oleh institusional (perusahaan asuransi, bank, perusahaan investasi dan kepemilikan institusi lain) akan dapat meningkatkan kepercayaan investor atas efektifiktas pemanfaatan aktiva perusahaan dalam menghasilkan laba dan pemborosan yang dilakukan oleh manajer (agent) sehingga hal ini akan dapat mempengaruhi cost of equity capital. Tindakan pengawasan perusahaan oleh kepemilikan institusional dapat mendorong manajer untuk lebih memfokuskan perhatiannya terhadap kinerja perusahaan sehingga akan mengurangi perilaku opportunistik atau mementingkan diri sendiri. Semakin besar tingkat kepemilikan saham oleh investor institusional akan semakin efektif mekanisme kontrol terhadap kinerja manajemen untuk mencapai tujuan perusahaan untuk meningkatkan nilai perusahaan.

Penelitian ini memperlihatkan bahwa kepemilikan institusional tidak berpengaruh terhadap cost of equity capital pada perusahaan LQ-45 di BEI tahun 2015 2018. Hal ini ditunjukkan oleh hasil pengujian hipotesis yang menunjukkan bahwa $t_{\text {hitung }}$ bernilai negatif tapi nilainya lebih kecil dari nilai $t_{\text {tabel }}$ pada taraf signifikansi 0,05. Kepemilikan Institusional bukan merupakan prediktor yang baik untuk menjelaskan cost of equity capital, artinya bahwa besar kecilnya kepemilikan institusional tidak mempengaruhi perkembangan cost of equity capital pada perusahaan LQ-45 di BEI tahun 2015 - 2018.

Penelitian ini mendukung penelitian sebelumnya yang dilakukan oleh Sukarti dan Suwarti (2018) yang mengungkapkan bahwa kepemilikan institusional memiliki tidak berpengaruh signifikan terhadap cost of equity capital.

Penelitian ini juga membantah penelitian sebelumnya yang dilakukan oleh Babadi dan Banisaleh (2017) yang mengungkapkan bahwa adanya pengaruh negatif dan signifikan antara kepemilikan institusional terhadap cost of equity capital. Penelitian ini juga membantah hasil penelitian sebelumnya yang dilakukan oleh Amelia dan Yadnyana (2016) yang mengungkapkan bahwa adanya pengaruh negatif dan signifikan antara kepemilikan institusional terhadap cost of equity capital.

\subsubsection{Pengaruh Asimetri Informasi terhadap Cost of} Equity Capital pada Perusahaan LQ-45 di Bursa Efek Indonesia Tahun 2015 - 2018

Teori agency menyebutkan bahwa perbedaan kepentingan antara manajer (agent) dengan pemegang 
saham (principal) akan menghasilkan ketidakseimbangan informasi antara yang diterima oleh manajer dengan pemegang saham, dimana manajer lebih mengetahui informasi internal dan prospek perusahaan dimasa yang akan datang dibandingkan dengan pemegang saham. Ketidakseimbangan informasi antara yang diterima antara manajer dengan pemegang saham disebut asimetri informasi. Informasi yang berkualitas bagi investor berfungsi untuk menurunkan asimetri informasi, dimana semakin kecil asimetri informasi dan risiko yang diterima perusahaan akan dapat mempengaruhi cost of equity capital dikarenakan investor akan meminta tingkat pengembalian modal yang rendah.

Penelitian ini memperlihatkan bahwa asimetri informasi berpengaruh positif dan signifikan terhadap cost of equity capital. Hal ini diperlihatkan oleh hasil pengujian hipotesis yang menunjukkan menunjukkan bahwa nilai $t_{\text {hitung }}$ lebih besar dari $t_{\text {tabel }}$ pada taraf signifikansi 0,05 . Hasil tersebut menunjukkan bahwa asimetri informasi mampu menjadi prediktor yang baik dalam menjelaskan cost of equity capital yang berarti bahwa semakin tinggi asimetri informasi akan meningkatkan besarnya cost of equity capital pada perusahaan LQ-45 di Bursa Efek Indonesia Tahun 2015 $-2018$.

Hasil penelitian ini mendukung penelitian sebelumnya yang dilakukan oleh Admadianto (2017) dan Purwanto (2014) yang mengungkapkan bahwa asimetri informasi berpengaruh positif dan signifikan terhadap cost of equity capital. Semakin kecil asimetri informasi dalam perusahaan maka cost of equity capital juga akan menurun sehingga investor tidak akan ragu untuk berinvestasi, dan sebaliknya meningkatnya asimetri informasi akan menimbulkan cost of equity capital perusahaan menjadi meningkat.

Hasil penelitian ini membantah penelitian sebelumnya yang dilakukan oleh Astutik et.al (2018), yang mengungkapkan menunjukkan bahwa asimetri informasi tidak berpengaruh terhadap biaya modal ekuitas. Hasil ini juga berbeda dengan penelitian yang dilakukan oleh Sukarti dan Suwarti (2018) yang mengungkapkan bahwa asimetri informasi tidak berpengaruh terhadap cost of eqity capital.

4.2.4. Nilai Buku Ekuitas Memoderasi Hubungan Corporate Social Responsibility dengan Cost of Equity Capital pada Perusahaan LQ-45 di Bursa Efek Indonesia Tahun 2015 - 2018

Hasil penelitian ini telah membuktikan bahwa nilai buku ekuitas tidak mampu memoderasi hubungan antara corporate social responsilibility dengan cost of equity capital. Hal ini diperlihatkan oleh hasil pengujian hipotesis yang menunjukkan menunjukkan bahwa nilai $t_{\text {hitung }}$ lebih kecil dari tabel pada taraf signifikansi 0,05. Hasil tersebut menunjukkan bahwa interaksi antara nilai buku ekuitas dengan pengungkapan corporate social responsibility tidak mampu menjadi prediktor yang baik dalam menjelaskan cost of equity capital pada perusahaan LQ45 di Bursa Efek Indonesia Tahun 2015 - 2018.

Hasil penelitian ini membantah hasil penelitian sebelumnya yang diajukan oleh Yuniarta dan Agustini (2014) dan Agustini (2011) yang mengungkapkan bahwa nilai buku ekuitas mampu mempengaruhi hubungan pengungkapan corporate social responsibility (CSR) dengan cost of equity capital (CEC) yakni memperlemah pengaruh positif CSR terhadap CEC Hasil ini juga membantah penelitian Agustini (2011) yang juga menyatakan bahwa nilai buku ekuitas terbukti mempengaruhi hubungan pengungkapan corporate social responsibility (CSR) dengan cost of equity capital (CEC).

Nilai buku ekuitas menunjukkan ukuran kualitas laporan keuangan yang dilihat sebagai daya informasi angka-angka dalam laporan keuangan. Dalam penelitian ini nilai buku ekuitas adalah nilai modal ekuitas dibandingkan dengan jumlah saham yang beredar. Nilai buku ekuitas tersebut menunjukkan ukuran neraca atau aktiva bersih yang dimiliki oleh perusahaan. Nilai buku yang berasal dari neraca memberikan informasi tentang nilai bersih sumber daya perusahaan (Yuniarta dan Agustini, 2014).

Hasil penelitian ini menunjukkan bahwa pengungkapan corporate social responsibility yang diikuti dengan peningkatan nilai buku ekuitas tidak mempengaruhi perkembangan biaya modal ekuitas. Semakin besar pengungkapan informasi yang dilakukan oleh perusahaan dalam hal ini berupa pengungkapan CSR disertai dengan nilai buku ekuitas yang baik, tidak memberikan jaminan cost of equity capital-nya semakin rendah. Pengungkapan CSR dengan nilai buku ekuitas yang baik merupakan keuntungan potensial dari pengungkapan. Keuntungan tersebut berupa meningkatnya jumlah investor, mengurangi estimasi risiko, dan mengurangi asimetri informasi yang masing-masing menunjukkan pengurangan cost of equity capital.

\subsubsection{Nilai Buku Ekuitas Memoderasi Hubungan} Kepemilikan Institusional dengan Cost of Equity Capital pada Perusahaan LQ-45 di Bursa Efek Indonesia Tahun 2015 - 2018

Hasil penelitian ini telah membuktikan bahwa nilai buku ekuitas mampu memoderasi hubungan antara kepemilikan institusional dengan cost of equity capital. Hal ini diperlihatkan oleh hasil pengujian hipotesis yang menunjukkan menunjukkan bahwa nilai $t_{\text {hitung }}$ lebih besar dari $t_{\text {tabel }}$ pada taraf signifikansi 0,05. Hasil tersebut menunjukkan bahwa interaksi antara nilai buku ekuitas dengan kepemilikan institusional mampu menjadi prediktor yang baik dalam menjelaskan cost of equity capital pada perusahaan LQ-45 di Bursa Efek Indonesia Tahun 2015 - 2018.

Hasil penelitian ini menunjukkan bahwa besar kecilnya kepemilikan institusional yang diikuti dengan peningkatan nilai buku ekuitas mempengaruhi perkembangan biaya modal ekuitas. Kepemilikan 
institusional yang tinggi memungkinkan pengawasan yang dilakukan oleh institusi yang menjadi pemilik saham terhadap kegiatan operasional perusahaan. Apabila pengawasan tersebut diikuti dengan adanya informasi yang berkualitas yang dilaporkan dalam laporan keuangan, maka kondisi tersebut akan menguntungkan investor sehingga akan memperbesar jumlah biaya modal ekuitas yang dikeluarkan oleh perusahaan.

4.2.6. Nilai Buku Ekuitas Memoderasi Hubungan Asimetri Informasi Cost of Equity Capital pada Perusahaan LQ-45 di Bursa Efek Indonesia Tahun 2015 - 2018

Hasil penelitian ini telah membuktikan bahwa nilai buku ekuitas mampu memoderasi hubungan antara asimetri informasi dengan cost of equity capital. Hal ini diperlihatkan oleh hasil pengujian hipotesis yang menunjukkan menunjukkan bahwa nilai $t_{\text {hitung }}$ lebih kecil dari $t_{\text {tabel }}$ pada taraf signifikansi 0,05 . Hasil tersebut menunjukkan bahwa interaksi antara nilai buku ekuitas dengan asimetri informasi mampu menjadi prediktor yang baik dalam menjelaskan cost of equity capital pada perusahaan LQ-45 di Bursa Efek Indonesia Tahun 2015 - 2018.

Hasil penelitian ini menunjukkan bahwa tingginya asimetri informasi yang diikuti dengan peningkatan nilai buku ekuitas justru memperkecil nilai biaya modal ekuitas. Semakin besar asimetri informasi disertai dengan nilai buku ekuitas yang baik, maka semakin rendah cost of equity capital-nya. Adanya asimetri infromasi menunjukkan kemungkinan semakin leluasanya manajer perusahaan melakukan manipulasi laba, dan apabila hal itu disertai dengan daya informasi dalam laporan keuangan yang baik, maka perilaku manajer tersebut semakin sulit diketahui oleh investor yang akibatnya berimbas pada turunnya nilai biaya modal ekuitas yang dikeluarkan perusahaan.

\section{SIMPULAN DAN SARAN}

\subsection{Simpulan}

Berdasarkan hasil analisis data yang telah diuraikan pada bab sebelumnya, maka dapat diambil kesimpulan sebagai berikut.

1. Corporate social responsibillity tidak berpengaruh terhadap cost of equity capital pada perusahaan LQ45 di Bursa Efek Indonesia Tahun 2015 - 2018, hal ini berarti bahwa pengungkapan CSR tidak memberikan dampak signifikan terhadap perkembangan biaya modal ekuitas yang dikeluarkan perusahaan.

2. Kepemilikan institusional tidak berpengaruh terhadap cost of equity capital pada perusahaan LQ45 di Bursa Efek Indonesia Tahun 2015 - 2018, hal ini berarti bahwa besar kecilnya kepemilikan institusional tidak memberikan dampak signifikan terhadap perkembangan biaya modal ekuitas yang dikeluarkan perusahaan.

3. Asimetri informasi berpengaruh positif dan signifikan terhadap cost of equity capital pada perusahaan LQ-45 di Bursa Efek Indonesia Tahun 2015 - 2018. Hal ini berarti bahwa semakin tinggi asimetri informasi akan semakin meningkatkan nilai biaya modal ekuitas yang dikeluarkan perusahaan.

4. Interaksi antara nilai buku ekuitas dengan corporate social responsibility tidak berpengaruh terhadap cost of equity capital pada perusahaan LQ-45 di BEI tahun 2015 - 2018. Hal ini berarti bahwa nilai buku ekuitas tidak mampu memoderasi hubungan antara corporate social responsibility dengan Cost Of Equity Capital.

5. Interaksi antara nilai buku ekuitas dengan kepemilikan institusional berpengaruh positif dan signifikan terhadap cost of equity capital pada perusahaan LQ-45 di BEI tahun 2015 - 2018. Hal ini berarti bahwa nilai buku ekuitas mampu memperkuat atau memoderasi hubungan antara kepemilikan institusional dengan Cost Of Equity Capital.

6. Interaksi antara nilai buku ekuitas dengan asimetri informasi berpengaruh negatif dan signifikan terhadap cost of equity capital pada perusahaan LQ45 di BEI tahun 2015 - 2018. Hal ini berarti bahwa nilai buku ekuitas mampu memperkuat atau memoderasi hubungan antara asimeteri informasi dengan Cost Of Equity Capital

\subsection{Saran}

1. Perusahaan yang tergabung dalam LQ-45 di BEI tahun 2015 - 2018 supaya memperhatikan faktor asimetri informasi dalam pengelolaan perusahaannya karena dengan semakin banyaknya informasi diterima oleh investor atau pemegang saham akan dapat berpengaruh signifikan menurunkan biaya modal.

2. Perusahaan yang tergabung dalam LQ-45 di BEI tahun 2015 - 2018 supaya memperhatikan nilai buku ekuitas, dimana nilai buku ekuitas mampu mempengaruhi hubungan kepemilikan institusional dengan biaya modal sehingga dengan semakin meningkatnya kepemilikan institutional sebagai pemegang saham dengan nilai buku ekuitas yang meningkat akan dapat berpengaruh signifikan menurunkan biaya modal.

3. Perusahaan dan para investor yang tergabung dalam LQ-45 di BEI tahun 2015 - 2018 supaya memperhatikan nilai buku ekuitas, dimana nilai buku ekuitas mampu mempengaruhi hubungan asimetri informasi dengan biaya modal sehingga meskipun meningkatnya asimteri informasi dengan nilai buku ekuitas meningkat akan dapat berpengaruh signifikan menurunkan biaya modal.

4. Bagi peneliti selanjutnya agar dapat menggunakan periode penelitian yang lebih panjang dan menambahkan variabel-variabel lain yang mempengaruhi cost of equity capital seperti tata 
kelola perusahaan, pengungkapan informasi dalam laporan keuangan, struktur modal perusahaan, kinerja keuangan dan lain sebagainya sehingga diharap penelitian selanjutnya akan dapat lebih sempurna.

\section{DAFTAR REFERENSI}

Admadianto, H.N. 2017. Pengaruh Manajemen Laba, Pengungkapan Modal Intelektual, Asimetri Informasi dan Nilai buku ekuitas Terhadap Cost Of Equity Capital (Studi Empiris Pada Perusahaan Yang Tergabung Dalam Indeks JII dan LQ-45 Selama Tahun 2004-2015). Tesis Naskah Publikasi. Magister Akuntansi Fakultas Pasca Sarjana Universitas Muhamadiyah Surakarta.

Agustini, Yuli. 2011. Pengaruh Nilai buku ekuitas pada Hubungan Pengungkapan Corporate Social Responsibility dengan Cost of Equity Capital. Tesis Program Pascasarjana Universitas Udayana Bali.

Amelia, Viona Rizqi dan Yandyana, I Ketut. 2016. Pengaruh Good Corporate Governance, Kepemilikan Keluarga Dan Kepemilikan Instituional Pada Biaya Ekuitas Perusahaan Manufaktur. ISSN. 2302-8556.

Ashbaugh, H. D,W. Collins, dan R, Lafond. 2004. Corporate Governance and The Cost of Equity Capital. Working Paper. Available online at http://papers.ssrn.com.

Astutik, Rika. Chayono, Dwi dan A, F,Kamelia, Ibna. 2018. Information Asymetry and Profit Management On Cost Of Equity Capital. The International Journal Of Business Review, Vol.1.

Cornett, M. M., Marcus, A. J., Saunders, A., and Tehranian, H. 2006. Earnings Management, Corporate Governance, and True Financial Performance. Working Paper. Southern Illinois University, Carbondale.

Garriga E. dan Melé D. 2004. Corporate Social Responsibility Theories - Mapping the territory. Journal of Business Ethics. Vol 53. No.1. hal. 5255.

Ghozali, Imam. 2011. Analisis Multivariate dengan Program SPSS. Semarang: Badan Penerbit Universitas Diponegoro.

Ghozali, Imam. 2014. Aplikasi Analisis Multivariate dengan Program SPSS. Semarang: Badan Penerbit Universitas Diponegoro.

Gujarati, Damodar. 2003. Ekometri Dasar. Jakarta, Erlangga

Hadi, Nur. 2011. Corporate Social Responsibility. Yogyakarta: Graha.

Hanafi, Mamduh. 2014, Manajemen Keuangan. Yogyakarta: BPFE
Hughes, J. J, Liu, and J, Liu. 2006. Information Asymmetry, Diversification, and Cost of Capital. The Accounting Review, 82: 705-730.

Jansen, Joëla M. A. 2017, The effect of corporate social responsibility on the cost of equity from a legal origin and cultural perspective. Thesis. University of Groningen and Uppsala University.

Jogiyanto, Hartono 2010. Teori Portofolio dan Analisis Investasi, Edisi Kedua, Yogyakarta: BPFE

Keown, Arthur. J, Scott, David. F, Martin, John.D, dan Petty, J. William. 2000. Dasar-dasar Manajemen Keuangan. Edisi 2. Jakarta: Salemba Empat. 443480.

Mardikanto, Totok. 2018. Tanggung Jawab Sosial Korporasi. Cetakan Kedua. Bandung: Alfabeta

Naimah, Zahroh. 2014. Relevansi Nilai Informasi Akuntansi : Suatu Kajian Teoritis. Jurnal Buletin Studi Ekonomi Vo.19 No.01.

Naimah, Zahroh dan Utama, Siddharta. 2006. Pengaruh nilai buku ekuitas, pertumbuhan, dan profitabilitas perusahaan terhadap koefisien respon laba dan koefisien respon nilai buku ekuitas: Studi pada perusahaan manufaktur di BEJ. Simposium Nasional Akuntansi IX, Padang. V.

Pratiwi, A, Nurkholis dan A, Ghofar. 2015. Pengaruh Corporate Governance dan Struktur Kepemilikan terhadap Asimetri Informasi. JAAI Volume 19 Nomor 2, Desember 2015: 99 - 111.

Purwanto, Agus. 2014. Pengaruh Manajemen Laba, Asymmetry Information dan Pengungkapan Sukarela Terhadap Biaya Modal. Simposium Nasional Akuntansi XV Maret 2014 Banjarmasin.

Rahman, R. 2010. Corporate Social Responsibility : Antara Teori dan Kenyataan. Yogyakarta: Media Pressindo.

Razali, Mohd Waliuddin, Mohd. Wong Yik Fui, Shazali Shaharuddin, Akmal Hisham Tak, dan Mohd Uzairi Ahmad Hajazi. 2017. Corporate Social Responsibility Disclosure and Cost of Equity Capital in Industrial Product Industry. Journal of Humanities, Language, Culture and Business (HLCB) Vol. 1: no. 2 (2017) page 168180 | www.icohlcb.com |eISSN : 01268147|.

Rianingtyas, Riris Arista dan Trisnawati, Rina. 2017. Pengaruh Pengungkapan CSR, Manajemen Laba dan Asimetri Informasi Terhadap Cost Of Equity Capital Dengan Cost of Equity Capital Sebagai Variabel Moderating Pada Perusahaan Yang Terdaftar di Index LQ-45 Tahun 2010-2015. Seminar Nasional dan The 4th Call For Syariah Paper, ISSN 2460-0784.

Sirait, Shanty, D.Y. dan Siregar, S.V. 2012. Hubungan Antara Biaya Modal Ekuitas dengan Tingkat Pengungkapan Tanggung Jawab Sosial dan Modal Intelektual pada Sektor Perbankan di Indonesia. 
Jurnal Akuntansi \& Auditing Volume 9/No.1/November 2012: 1-96.

Sugiarto, 2009. Struktur Modal, Struktur Kepemilikan Perusahaan, Permasalahan Keagenan \& Informasi Asimetri.Yogyakarta.Graha Ilmu.

Suharsono, Riyanto Setiawan dan Gusti Ayu Putu Wulan Rahmasari. 2013. Pengaruh Pengungkapan Corporate Social Responsibility (CSR) terhadap Cost of Equity Capital (CEC) dengan Kepemilikan Institusional sebagai Variabel Pemoderasi. Jurnal Ilmiah Akuntansi dan Humanika, JINAH Vol 2 No. 2, Juni 2013. ISSN 2089-3310.

Sukarti dan Suwarti, T. 2018. Pengaruh Pengungkapan CSR, Asimetri Informasi, Nilai buku ekuitas, dan Kepemilikan Institusional terhadap Cost Of Equity. Prosiding SENDI_U 2018 ISBN: 978979-3649-99-3.

Suwardjono. 2008. Teori Akuntansi: Perekayasaan Pelaporan Keuangan. Edisi ketiga, BPFEYogyakarta

Tarjo. 2010. Pengaruh Struktur Kepemilikan dalam Mekanisme Corporate Governance terhadap Cost of Equity Capital. AKRUAL 1 (1) (2009): 89-104 e-ISSN: 2502-6380.

Utami, W.2005. Pengaruh Managemen Laba Terhadap Biaya Modal Ekuitas (Studi pada Perusahaan Publik Sektor Manafaktur. Simposium Nasional Akuntansi VIII, Solo.

Yuniarta, G.A dan Agustini, Yuli. 2014. Nilai buku ekuitas Memoderasi Pengaruh Positif Corporate Social Responsibility Terhadap Cost of Equity Capital. Jurnal Keuangan Dan Perbankan.

Undang Undang Nomor 25 Tahun 2007 Tentang Penanaman Modal.

, Undang Undang Nomor 40 Tahun 2007 Tentang Perseroan Terbatas.

Keputusan Badan Pengawas Pasar Modal Dan Lembaga Keuangan Nomor KEP431/BL/2012. 